\title{
Determinants Of Destination Image And Competitiveness In Sibu Heritage Trail: A PLS-SEM Approach
}

\author{
YING-SIN, CHIN ${ }^{1}$, ABANG AZLAN MOHAMAD², MAY-CHIUN, LO ${ }^{3}$, MOHAMAD KADIM SUAIDI ${ }^{4}$, \\ SHIAW-TONG, HA \\ ${ }^{1}$ Faculty of Economics and Business, UNIVERSITI MALAYSIA SARAWAK, MALAYSIA. \\ E-mail: yingsin95@gmail.com \\ ${ }^{2}$ Faculty of Economics and Business, UNIVERSITI MALAYSIA SARAWAK, MALAYSIA. \\ E-mail: maazlan@unimas.my \\ ${ }^{3}$ Faculty of Economics and Business, UNIVERSITI MALAYSIA SARAWAK, MALAYSIA \\ E-mail: mclo@unimas.my \\ ${ }^{4}$ Chancellery, UNIVERSITI MALAYSIA SARAWAK, MALAYSIA. E-mail: kadim@unimas.my \\ ${ }^{5}$ Faculty of Economics and Business, UNIVERSITI MALAYSIA SARAWAK, MALAYSIA. \\ E-mail: revetong@gmail.com
}

\begin{abstract}
Tourism is the largest sector in the world and contributes significantly to the economies of the most advanced and developing countries. A major concern on limited resources and acknowledgement of competitiveness all led to the expansion of the literature on the competitiveness of tourism destinations. While there are limited studies investigating destination image and destination competitiveness, no studies have been found to examine the determinants of destination image and destination competitiveness. Thus, the present study attempts to explore whether accessibility quality, accommodation quality, destination attractiveness \& resources on destination image and competitiveness. Data were collected from 132 tourists who have visited Sibu Heritage Trail. SmartPLS 3.0 was used to assess the developed model. The results highlighted that accessibility quality was positively and significantly related to the destination image. Besides, destination attractiveness and resources were found to be positively and significantly related to destination competitiveness as well as destination image. On the other hand, destination image was also found to have a significant and positive impact on destination competitiveness. The implications and limitations of the present study were further discussed.
\end{abstract}

Keywords: Accessibility Quality; Accommodation Quality; Destination Resources and Attractiveness; Destination Image; Destination Competitiveness.

JEL Classification: C1, L2.

Received: March 4, 2021

Accepted: June 12, 2021 